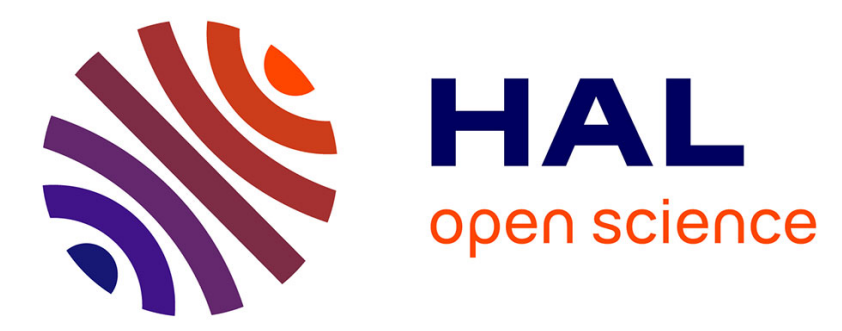

\title{
Role of CB receptors in neuroprotective effects of cannabinoids
}

Javier Fernández-Ruiz, María Ruth Pazos, Moisés García-Arencibia, Onintza Sagredo, José A. Ramos

\section{- To cite this version:}

Javier Fernández-Ruiz, María Ruth Pazos, Moisés García-Arencibia, Onintza Sagredo, José A. Ramos. Role of CB receptors in neuroprotective effects of cannabinoids. Molecular and Cellular Endocrinology, 2008, 286 (1-2), 10.1016/j.mce.2008.01.001 . hal-00531980

\section{HAL Id: hal-00531980 \\ https://hal.science/hal-00531980}

Submitted on 4 Nov 2010

HAL is a multi-disciplinary open access archive for the deposit and dissemination of scientific research documents, whether they are published or not. The documents may come from teaching and research institutions in France or abroad, or from public or private research centers.
L'archive ouverte pluridisciplinaire HAL, est destinée au dépôt et à la diffusion de documents scientifiques de niveau recherche, publiés ou non, émanant des établissements d'enseignement et de recherche français ou étrangers, des laboratoires publics ou privés. 


\section{Accepted Manuscript}

Title: Role of $\mathrm{CB}_{2}$ receptors in neuroprotective effects of cannabinoids

Authors: Javier Fernández-Ruiz, María Ruth Pazos, Moisés

García-Arencibia, Onintza Sagredo, José A. Ramos

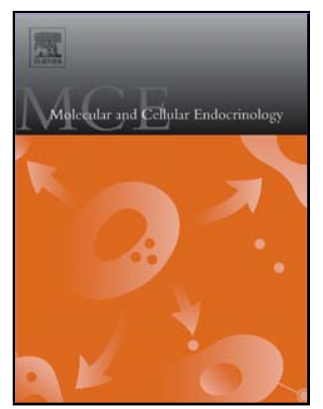

PII:

S0303-7207(08)00005-1

DOI: doi:10.1016/j.mce.2008.01.001

Reference: MCE 6783

To appear in: $\quad$ Molecular and Cellular Endocrinology

Received date: $\quad 24-12-2007$

Revised date: $\quad$ 4-1-2008

Accepted date: $\quad 4-1-2008$

Please cite this article as: Fernández-Ruiz, J., Pazos, M.R., García-Arencibia, M., Sagredo, O., Ramos, J.A., Role of $\mathrm{CB}_{2}$ receptors in neuroprotective effects of cannabinoids, Molecular and Cellular Endocrinology (2007), doi:10.1016/j.mce.2008.01.001

This is a PDF file of an unedited manuscript that has been accepted for publication. As a service to our customers we are providing this early version of the manuscript. The manuscript will undergo copyediting, typesetting, and review of the resulting proof before it is published in its final form. Please note that during the production process errors may be discovered which could affect the content, and all legal disclaimers that apply to the journal pertain. 


\section{Role of $\mathrm{CB}_{2}$ receptors in neuroprotective effects of cannabinoids}

Javier Fernández-Ruiz, María Ruth Pazos, Moisés García-Arencibia, Onintza Sagredo and José A. Ramos

Department of Biochemistry and Molecular Biology and "Centro de Investigación Biomédica en Red sobre Enfermedades Neurodegenerativas (CIBERNED)", Faculty of Medicine, Complutense University, Madrid, Spain

Short title: $\quad \mathrm{CB}_{2}$ receptors and neuroprotection

Corresponding author: Javier Fernández-Ruiz

Department of Biochemistry and Molecular Biology

Faculty of Medicine, Complutense University

28040 Madrid, Spain

Phone: 34-913941450

Fax: 34-913941691

E-mail:jjfr@med.ucm.es (or J.Fernandez-Ruiz@ciberned.es) 


\begin{abstract}
$\mathrm{CB}_{2}$ receptors, the so-called peripheral cannabinoid receptor type, were first described in the immune system, but they have been recently identified in the brain in healthy conditions and, in particular, after several types of cytotoxic stimuli. Specifically, $\mathrm{CB}_{2}$ receptors were identified in microglial cells, astrocytes and, to a lesser extent, in certain subpopulations of neurons. Given the lack of psychoactivity demonstrated by selective $\mathrm{CB}_{2}$ receptor agonists, this receptor becomes an interesting target for the treatment of neurological diseases, in particular, the case of certain neurodegenerative disorders in which induction/up-regulation of $\mathrm{CB}_{2}$ receptors has been already demonstrated. These disorders include Alzheimer's disease, Huntington's chorea, amyotrophic lateral sclerosis and others. Interestingly, in experimental models of these disorders, the activation of $\mathrm{CB}_{2}$ receptors has been related to a delayed progression of neurodegenerative events, in particular, those related to the toxic influence of microglial cells on neuronal homeostasis. The present article will review the evidence supporting that $\mathrm{CB}_{2}$ receptors might represent a key element in the endogenous response against different types of cytotoxic events, and that this receptor type may be a clinicallypromising target for the control of brain damage in neurodegenerative disorders.
\end{abstract}

\title{
List of contents
}

The $\mathrm{CB}_{2}$ receptor within the cannabinoid signaling system

- $\mathrm{CB}_{2}$ receptor: pharmacological characteristics

- $\mathrm{CB}_{2}$ receptor: tissue and cell distribution

- $\mathrm{CB}_{2}$ receptor: signaling mechanisms

$\mathrm{CB}_{2}$ receptor and neuroprotection

- Up-regulation/induction of $\mathrm{CB}_{2}$ receptors in pathological brain

- Neuroprotective action of $\mathrm{CB}_{2}$ receptors

- Control of glial-mediated effects by $\mathrm{CB}_{2}$ receptors

Closing remarks

Key words: $\quad \mathrm{CB}_{2}$ receptors, $\mathrm{CB}_{2}$ receptors agonists, cannabinoids, neurodegenerative disorders, local inflammation, reactive microglia 


\section{The $\mathrm{CB}_{2}$ receptor within the cannabinoid signaling system}

Studying the mechanism(s) of action of cannabinoids, the singular bi- and tricyclic compounds found in Cannabis sativa, several researchers identified in the 80s and 90s a novel intercellular signaling system, the so-called endocannabinoid system, that plays important modulatory functions in the brain and also in the periphery (for review, see Mackie, 2006). This identification started with the discovery of a membrane receptor, abundantly located in the brain although also present in the periphery, first called cannabinoid receptor and lately $\mathrm{CB}_{1}$ receptor, whose activation is directly related to the psychoactivity typical of certain plant-derived cannabinoids (Pertwee, 2005). However, this is not the only receptor that may be activated by cannabinoids. In 1993, Munro and coworkers (Munro et al., 1993) cloned a second cannabinoid receptor type, the so-called $\mathrm{CB}_{2}$ receptor, that is not involved in psychoactive effects of cannabinoids and, accordingly, it was initially found in the periphery, particularly in immune cells (for a recent review, see Raitio et al., 2005). This "peripheral cannabinoid receptor" is located in chromosome $1 \mathrm{p} 36$ in the human and encodes a protein of 360 amino acids with a $44 \%$ homology with the $\mathrm{CB}_{1}$ receptor, although the homology is greater in the transmembrane domain (approximately 68\%).

\section{$\underline{\mathrm{CB}_{2}} \underline{\text { receptor: pharmacological characteristics }}$}

The pharmacology of $\mathrm{CB}_{2}$ receptors is in part similar to $\mathrm{CB}_{1}$ receptors (e.g. most plantderived and synthetic cannabinoid agonists activate $\mathrm{CB}_{2}$ receptors), although the affinity and/or potency at which these agonists bind and/or activate $\mathrm{CB}_{2}$ receptors present some interesting differences compared to $\mathrm{CB}_{1}$ receptors (Pertwee, 2005; Fernández-Ruiz et al., 2007). This also happens in the case of endocannabinoid ligands, since anandamide (arachidonoylethanolamide, AEA) was reported to be a weaker agonist for $\mathrm{CB}_{1}$ receptors and not to significantly bind to $\mathrm{CB}_{2}$ receptors (Mechoulam and Hanus, 2000; Sugiura et al., 2006), except in pathological conditions (Eljaschewitsch et al., 2006), whereas several studies suggested that 2-arachidonoylglycerol (2-AG) is an endogenous agonist for $\mathrm{CB}_{2}$ receptors (Sugiura et al., 2006). It appears obvious that these pharmacological differences are the consequence, among others, of certain differences in chemical structures of cannabinoid agonists, differences that have been used to design selective synthetic $\mathrm{CB}_{2}$ receptor agonists. This is the case of compounds such as JWH-133 and their analogs (Huffman, 2005), HU-308 (Hanus et al., 1999) and AM1241 (Malan et al., 2001), which represent novel tools to activate 
selectively $\mathrm{CB}_{2}$ receptors without the concomitant activation of the $\mathrm{CB}_{1}$ receptor type. This represents an important goal since, although cannabinoids have a favorable drug safety profile, their use in the clinic is severely limited by the psychoactive effects elicited by most of cannabinoid agonists and mediated by the activation of $\mathrm{CB}_{1}$ receptors. Therefore, an attractive alternative is to target $\mathrm{CB}_{2}$ receptors selectively with the above-described agonists which are completely devoid of psychoactive effects, although they might exhibit other side effects such as immune suppression (Pertwee, 2005). Their potential for the treatment of certain neurological diseases is presently being examined in multiple preclinical studies, including several neuroinflammatory/neurodegenerative disorders in which $\mathrm{CB}_{2}$ receptor agonists might serve to delay the progression of neuronal damage (Fernández-Ruiz et al., 2007, for a recent review). On the other hand, selective antagonists for the $\mathrm{CB}_{2}$ receptor are also currently available, and constitute important tools to elucidate the involvement of this receptor type in specific cellular functions (for review, see Pertwee, 2005; Fernández-Ruiz et al., 2007).

\section{$\underline{\mathrm{CB}}_{2}$ receptor: tissue and cell distribution}

As mentioned above, the first studies that explored the tissue and cell distribution of $\mathrm{CB}_{2}$ receptors indicated that this cannabinoid receptor type was exclusively present in tissues and cells of the immune system (e.g. spleen macrophages, tonsils, B cells and natural killer cells, monocytes, neutrophils and T cells; Howlett et al., 2002; Pertwee, 2005; Fernández-Ruiz et al., 2007, for review), being absent from the CNS (Lynn and Herkenham, 1994), in notable contrast with the well-known distribution of $\mathrm{CB}_{1}$ receptors. Further studies suggested that, although absent from the CNS in normal conditions, this receptor might be induced in glial cells, in particular reactive microglia, in response to different damaging conditions associated with local inflammatory events (see Fernández-Ruiz et al., 2007, for review). Lastly, recent studies have proposed that $\mathrm{CB}_{2}$ receptors may be present in the brain even in healthy conditions (Onaivi et al., 2006), despite this issue has remained controversial due to uncertainty of experimental approaches used or of some methodological tools available (e.g. anti- $\mathrm{CB}_{2}$ antibody). These studies identified $\mathrm{CB}_{2}$ receptors in glial cells, including microglia and astrocytes (Stella, 2004; Nuñez et al., 2004; Maresz et al., 2005), neural (Palazuelos et al., 2006) and oligodendroglial (Molina-Holgado et al., 2002) progenitors, and certain neuronal

subpopulations (Skaper et al., 1996; Ross et al., 2001; Stander et al., 2005; Wotherspoon et al., 2005; Van Sickle et al., 2005; Beltramo et al., 2006) in different brain structures of 
various species, including human samples (Nuñez et al., 2004) and using either in vivo or in vitro approaches.

\section{$\underline{\mathrm{CB}_{2}} \underline{\text { receptor: signaling mechanisms }}$}

$\mathrm{CB}_{2}$ receptors belong to the seven-transmembrane domain, G-protein-coupled receptor class (Howlett et al., 2002). They are coupled to $\mathrm{G}_{\mathrm{i} / \mathrm{o}}$ proteins, so that their activation, in various cell types expressing the receptor either naturally or heterologously, is associated with classic intracellular responses: (i) the inhibition of adenylyl cyclase and the cAMP/protein kinase A (PKA)-dependent pathway (Howlett et al., 2002); and (ii) the stimulation of mitogenactivated protein kinase (MAPK) cascades, specifically the extracellular signal-regulated kinase (ERK) (Bouaboula et al., 1996; Carrier et al., 2004; Palazuelos et al., 2006) and the p38 MAPK cascades (Gertsch et al., 2004; Herrera et al., 2005). In addition, the activation of $\mathrm{CB}_{2}$ receptors has been also linked to the stimulation of additional intracellular pathways including the phosphatidylinositol 3-kinase (PI3K)/Akt pathway (Molina-Holgado et al., 2002; Samson et al., 2003; Palazuelos et al., 2006), which has been associated with prosurvival effects, and the de novo synthesis of the sphingolipid messenger ceramide (Sánchez et al., 2001; Carracedo et al., 2006a and 2006b), which has been linked with the pro-apoptotic effects of cannabinoids.

\section{$\mathrm{CB}_{2}$ receptor and neuroprotection}

Most of physiological functions associated with the $\mathrm{CB}_{2}$ receptor deal with different types of immunological effects given the predominance of this receptor type over the $\mathrm{CB}_{1}$ receptor in immune tissues. However, its recent description in certain brain regions allowed relate this receptor type to those neurobiological processes located in those region, for example, the control of pain, brain reward, emotion and others (Onaivi et al., 2006, for review). An important point is the implication of the $\mathrm{CB}_{2}$ receptor in processes related to the control of proliferation (Carrier et al., 2004; Palazuelos et al., 2006), differentiation (Sánchez et al., 2001; Alberich Jorda et al., 2004; Palazuelos et al., 2006) and survival (Sánchez et al., 2001) of neural cells. That the $\mathrm{CB}_{2}$ receptor plays a role in these key cell processes is the basis for the proposal that selective agonists of this receptor type may act on "two sides of a coin" by providing cytoprotection of healthy neural cells or by eliciting apoptosis of tumoral cells (see Fernández-Ruiz et al., 2007, for a recent review). This review will focus only in the first of 
these two properties, namely, their capability to arrest/delay brain damage in different neurodegenerative disorders, particularly in those that exhibit an important local inflammatory component associated with brain injury. This capability adds to other neuroprotective mechanisms elicited by different elements of the cannabinoid signaling system, in particular the $\mathrm{CB}_{1}$ receptor that has been associated with inhibition of glutamate release, decrease of cytosolic free $\mathrm{Ca}^{2+}$ concentration and vasodilation, effects that are overall capable to increase neuronal survival (see van der Stelt and Di Marzo, 2005; Fernández-Ruiz et al., 2005, for review). This potential, together with other cannabinoid receptor-independent properties (e.g., blockade of NMDA receptors, antioxidant activity; see Fernández-Ruiz et al., 2005, for review), allows cannabinoids to protect neurons from death and, accordingly, to be beneficial as novel therapies for acute brain injury (cerebral ischemia and trauma) and for chronic neurodegenerative disorders [e.g. Alzheimer's disease (AD), Parkinson's disease (PD), Huntington's disease (HD), amyotrophic lateral sclerosis (ALS) and multiple sclerosis (MS)].

\section{Up-regulation/induction of $\mathrm{CB}_{2}$ receptors in pathological brain}

Despite the present evidence indicating that $\mathrm{CB}_{2}$ receptors are present in the normal CNS of rodents and humans (Onaivi et al., 2006), it is likely that these receptors experience a marked elevation in discrete brain regions after pathological neuroinflammatory insults (FernándezRuiz et al., 2007). This might include either their up-regulation in cells that naturally express $\mathrm{CB}_{2}$ receptors (e.g. astrocytes; Stella, 2004) or their induction in cells that are recruited and activated in response to damaging stimuli (e.g. reactive microglial cells; Fernández-Ruiz et al., 2005 and 2007). This type of response has been observed in those structures undergoing neuronal damage: (i) in the rat brain following stroke (Ashton et al., 2007); (ii) in a rat model of HD (Fernández-Ruiz et al., 2005 and 2007); (iii) in SIV encephalitis (Benito et al., 2005) and HIV dementia (Romero et al., unpublished observations); (iv) in patients with Down's syndrome (Nuñez et al., 2007); (v) in the periphery of senile plaques in AD patients (Benito et al., 2003) and in an experimental model of $\mathrm{AD}$ in rats (Esposito et al., 2007); (vi) in a rat model of neuropathic pain (Zhang ey al., 2003); (vii) in patients with MS (Yiangou et al., 2006; Benito et al., 2007) and in an experimental model of MS in mice (Maresz et al., 2005); and (viii) also in patients with ALS (Yiangou et al., 2006). This up-regulatory response of $\mathrm{CB}_{2}$ receptors would be paralleled in some cases by equivalent responses of $\mathrm{CB}_{1}$ receptors and endocannabinoid ligands (Fernández-Ruiz et al., 2005 and 2007). Therefore, one may 
assume that the activation of the cannabinoid signaling system represents an endogenous response of the brain to maintain nerve cell homeostasis and to reduce the injury associated with conditions of excitotoxicity, inflammation, trauma, infection and other types of neurotoxic stimuli.

\section{Neuroprotective action of $\mathrm{CB}_{2}$ receptors}

In vivo or in vitro studies, using selective $\mathrm{CB}_{2}$ receptor agonists (e.g. HU-308, AM1241) or reversion with selective $\mathrm{CB}_{2}$ receptor antagonists (e.g. SR144528, AM630) of effects of nonselective agonists (e.g. WIN55,212-2), have demonstrated that this receptor may represent a pharmacologically valuable tool to protect neurons from death in a variety of acute and chronic neurodegenerative disorders (see Fernández-Ruiz et al., 2007, for review). This is the case of studies conducted in experimental models of perinatal hypoxia-ischemia (FernándezLópez et al., 2006), focal ischemis/reperfusion (Zhang et al., 2007), HD (Fernández-Ruiz et al., 2007), AD (Ramírez et al., 2005), ALS (Kim et al., 2006) and MS (Arévalo-Martín et al., 2003). However, this is not the case for PD in which only antioxidant cannabinoids, but not $\mathrm{CB}_{2}$ receptor agonists, provided neuroprotection (Lastres-Becker et al., 2005; GarcíaArencibia et al., 2007). In those neurodegenerative disorders where the activation of $\mathrm{CB}_{2}$ receptors is neuroprotective, this effect is, as expected, importantly linked to the recruitment, activation and migration of microglial cells to the sites of lesion and with the function of these cells on neuronal homeostasis (Eljaschewitsch et al., 2006; Fernández-Ruiz et al., 2007; see also the following section). In fact, $\mathrm{CB}_{2}$ receptor immunoreactivity has been identified in discrete subpopulations of microglia at the lesioned brain structures in most of these disorders, as has been detailed in the above section (Fernández-Ruiz et al., 2007, for review).

\section{$\underline{\text { Control of glial-mediated effects by } \mathrm{CB}_{2} \text { receptors }}$}

Given that $\mathrm{CB}_{2}$ receptors that provide neuroprotection in neurodegenerative disorders (see above section) seem to be those that are induced/up-regulated in glial cells in response to damaging stimuli, it appears likely to assume that their function within the endogenous protection against these stimuli would be related to limiting the toxic influence of microglia on neuronal homeostasis, to enhancing the protection exerted by astrocytes, or both. For instance, astrocytes have been reported to function as "neuroprotective cells" by generating pro-survival factors (e.g. neurotrophins) or metabolic substrates (e.g. ketone bodies, lactate) 
for neurons (see Chen and Swanson, 2003 for review). $\mathrm{CB}_{2}$ receptors have been identified in these glial cells at lesioned sites (Fernández-Ruiz et al., 2005). Therefore, it is possible that these receptors might enhance the generation of pro-survival factors or the support of metabolic substrates (see Figure 1 for an overview), but this possibility has not been determined yet. By contrast, microglial cells are recruited in response to brain injury and migrate at lesioned sites where they might play a primary "protective" function but that secondarily becomes toxic for neurons. It has been proposed, and demonstrated in a series of elegant studies (Puffenbarger et al., 2000; Facchinetti et al., 2003; Stella, 2004), that, in microglia, the up-regulatory response of $\mathrm{CB}_{2}$ receptors would be aimed at controlling the processes of proliferation, differentiation and migration of these cells (Walter et al., 2003; Carrier et al., 2004), as well as at limiting the magnitude of neurotoxic response exerted by microglial cells (Fernández-Ruiz et al., 2007). According to this, the activation of $\mathrm{CB}_{2}$ receptors would reduce the generation of neurotoxic factors, such as nitric oxide, proinflammatory cytokines and reactive oxygen species, by these reactive glial cells (see Fernández-Ruiz et al., 2007, for a recent review and Figure 1 for an overview). This type of response has been observed in animal models of perinatal hypoxia-ischemia (FernándezLópez et al., 2006) and HD (Fernández-Ruiz et al., 2005) where the activation of $\mathrm{CB}_{2}$ receptors reduced the release of proinflammatory factors, including nitric oxide, TNF $\alpha$, IL-1 and IL-6. By contrast, some of the antiinflammatory effects of cannabinoid receptor activation could be mediated by enhancing the action of anti-inflammatory molecules, such as IL-1ra (Molina-Holgado et al., 2003; Fernández-Ruiz et al., 2005 and 2007, for recent reviews).

\section{Closing remarks}

The studies reviewed here strongly support that brain $\mathrm{CB}_{2}$ receptors are important players in the control of neuroinflammatory events associated with conditions of brain damage of different etiologies. In pathological conditions, $\mathrm{CB}_{2}$ receptors are induced in cells that do not contain these receptors in healthy conditions (e.g. reactive microglia) or are up-regulated in cells that do contain a small number of these receptors. These responses are likely part of an endogenous mechanism of defense against a variety of brain-damaging insults, where they appear associated with equivalent responses in other elements of the cannabinoid signaling. Through the activation of these receptors, either in reactive microglial cells or in astrocytes, cannabinoid agonists might limit the toxic influence of microglia on neuronal homeostasis or potentiate the metabolic support exerted by astrocytes. Both effects, occurring independently 
or concomitantly, may enhance the possibilities of neuronal survival, so that this receptor represents a clinically-promising target for delaying/arresting the progression of neurodegeneration in acute and, in particular, in chronic neurological disorders.

\section{Acknowledgements}

We are indebted to our laboratory colleagues for their continuous support. Work in our laboratories is funded by "Ministerio de Educación y Ciencia" (SAF2006-11333), CIBERNED (CB06/05/0089) and "Comunidad de Madrid” (S-SAL-0261/2006).

\section{References}

Alberich Jordà M, Rayman N, Tas M, Verbakel SE, Battista N, van Lom K, Löwenberg B, Maccarrone M, Delwel R, 2004. The peripheral cannabinoid receptor CB2, frequently expressed on AML blasts, either induces a neutrophilic differentiation block or confers abnormal migration properties in a ligand-dependent manner. Blood 104, 526-534.

Arévalo-Martin A, Vela JM, Molina-Holgado E, Borrell J, Guaza C, 2003. Therapeutic action of cannabinoids in a murine model of multiple sclerosis. J. Neurosci. 23, 2511-2516.

Ashton JC, Rahman RM, Nair SM, Sutherland BA, Glass M, Appleton I, 2007. Cerebral hypoxia-ischemia and middle cerebral artery occlusion induce expression of the cannabinoid CB2 receptor in the brain. Neurosci. Lett. 412, 114-117.

Beltramo M, Bernardini N, Bertorelli R, Campanella M, Nicolussi E, Fredduzzi S, Reggiani A, 2006. CB2 receptor-mediated antihyperalgesia: possible direct involvement of neural mechanisms. Eur. J. Neurosci. 23, 1530-1538.

Benito C, Nuñez E, Tolon RM, Carrier EJ, Rabano A, Hillard CJ, Romero J, 2003. Cannabinoid CB2 receptors and fatty acid amide hydrolase are selectively overexpressed in neuritic plaque-associated glia in Alzheimer's disease brains. J. Neurosci. 23, 11136-11141. 
Benito C, Kim WK, Chavarria I, Hillard CJ, Mackie K, Tolon RM, Williams K, Romero J, 2005. A glial endogenous cannabinoid system is upregulated in the brains of macaques with simian immunodeficiency virus-induced encephalitis. J. Neurosci. 25, 2530-2536.

Benito C, Romero JP, Tolon RM, Clemente D, Docagne F, Hillard CJ, Guaza C, Romero J, 2007. Cannabinoid CB1 and CB2 receptors and fatty acid amide hydrolase are specific markers of plaque cell subtypes in human multiple sclerosis. J. Neurosci. 27, 2396-2402.

Bouaboula M, Poinot-Chazel C, Marchand J, Canat X, Bourrié B, Rinaldi-Carmona M, Calandra B, Le Fur G, Casellas P, 1996. Signaling pathway associated with stimulation of CB2 peripheral cannabinoid receptor. Involvement of both mitogen-activated protein kinase and induction of Krox-24 expression. Eur. J. Biochem. 237, 704-711.

Carracedo A, Lorente M, Egia A, Blázquez C, García S, Giroux V, Malicet C, Villuendas R, Gironella M, González-Feria L, Piris MA, Iovanna JL, Guzmán M, Velasco G, 2006a. The stress-regulated protein p8 mediates cannabinoid-induced apoptosis of tumor cells. Cancer Cell. 9, 301-312.

Carracedo A, Gironella M, Lorente M, Garcia S, Guzmán M, Velasco G, Iovanna JL, 2006 b. Cannabinoids induce apoptosis of pancreatic tumor cells via endoplasmic reticulum stressrelated genes. Cancer Res. 66, 6748-6755.

Carrier EJ, Kearn CS, Barkmeier AJ, Breese NM, Yang W, Nithipatikom K, Pfister SL, Campbell WB, Hillard CJ, 2004. Cultured rat microglial cells synthesize the endocannabinoid 2-arachidonylglycerol, which increases proliferation via a CB2 receptor-dependent mechanism. Mol. Pharmacol. 65, 999-1007.

Chen Y, Swanson RA, 2003. Astrocytes and brain injury. J. Cereb. Blood Flow. Metab. 23, 137-149.

Eljaschewitsch E, Witting A, Mawrin C, Lee T, Schmidt PM, Wolf S, Hoertnagl H, Raine CS, Schneider-Stock R, Nitsch R, Ullrich O, 2006. The endocannabinoid anandamide protects neurons during CNS inflammation by induction of MKP-1 in microglial cells. Neuron 49, 6779. 
Esposito G, Iuvone T, Savani C, Scuderi C, DE Filippis D, Papa M, DI Marzo V, Steardo L, 2007. Opposing control of cannabinoid receptor stimulation on amyloid- $\beta$ induced reactive gliosis: in vitro and in vivo evidence. J. Pharmacol. Exp. Ther. 322, 1144-1152.

Facchinetti F, Del Giudice E, Furegato S, Passarotto M, Leon A, 2003. Cannabinoids ablate release of TNFalpha in rat microglial cells stimulated with lypopolysaccharide. Glia 41, 161168.

Fernández-López D, Martínez-Orgado J, Nuñez E, Romero J, Lorenzo P, Moro MA, Lizasoain I, 2006. Characterization of the neuroprotective effect of the cannabinoid agonist WIN-55212 in an in vitro model of hypoxic-ischemic brain damage in newborn rats. Pediatr. Res. 60, 169-173.

Fernández-Ruiz J, González S, Romero J, Ramos JA, 2005. Cannabinoids in Neurodegeneration and Neuroprotection. In: Cannabinoids as Therapeutics (MDT), Mechoulam R (ed.), Birkhaüser Verlag, Switzerland, 79-109.

Fernández-Ruiz J, Romero J, Velasco G, Tolón RM, Ramos JA, Guzmán M, 2007. Cannabinoid $\mathrm{CB}_{2}$ receptor: a new target for the control of neural cell survival? Trends Pharmacol. Sci. 28, 39-45.

García-Arencibia M, González S, de Lago E, Ramos JA, Mechoulam R, Fernández-Ruiz J, 2007. Evaluation of the neuroprotective effect of cannabinoids in a rat model of Parkinson's disease: importance of antioxidant and cannabinoid receptor-independent properties. Brain Res. 1134, 162-170.

Gertsch J, Schoop R, Kuenzle U, Suter A, 2004. Echinacea alkylamides modulate TNF-alpha gene expression via cannabinoid receptor CB2 and multiple signal transduction pathways. FEBS Lett. 577, 563-569.

Hanus L, Breuer A, Tchilibon S, Shiloah S, Goldenberg D, Horowitz M, Pertwee RG, Ross RA, Mechoulam R, Fride E, 1999. HU-308: a specific agonist for CB2, a peripheral cannabinoid receptor. Proc. Natl. Acad. Sci. USA 96, 14228-1433. 
Herrera B, Carracedo A, Diez-Zaera M, Guzmán M, Velasco G, 2005. p38 MAPK is involved in CB2 receptor-induced apoptosis of human leukaemia cells. FEBS Lett. 579, 5084-5088.

Howlett AC, Barth F, Bonner TI, Cabral G, Casellas P, Devane WA, Felder CC, Herkenham M, Mackie K, Martin BR, Mechoulam R, Pertwee RG, 2002. International Union of Pharmacology. XXVII. Classification of cannabinoid receptors. Pharmacol. Rev. 54, 161-202.

Huffman JW, 2005. CB2 receptor ligands. Mini Rev. Med. Chem. 5, 641-649

Kim K, Moore DH, Makriyannis A, Abood ME, 2006. AM1241, a cannabinoid CB2 receptor selective compound, delays disease progression in a mouse model of amyotrophic lateral sclerosis. Eur. J. Pharmacol. 542, 100-105.

Lastres-Becker I, Molina-Holgado F, Ramos JA, Mechoulam R, Fernández-Ruiz J, 2005. Cannabinoids provide neuroprotection against 6-hydroxydopamine toxicity in vivo and in vitro: relevance to Parkinson's disease. Neurobiol. Dis. 19, 96-107.

Lynn AB, Herkenham M, 1994. Localization of cannabinoid receptors and nonsaturable highdensity cannabinoid binding sites in peripheral tissues of the rat: implications for receptormediated immune modulation by cannabinoids. J. Pharmacol. Exp. Ther. 268, 1612-1623.

Mackie K, 2006. Cannabinoid receptors as therapeutic targets. Annu. Rev. Pharmacol. Toxicol. 46, 101-122.

Malan TP Jr, Ibrahim MM, Deng H, Liu Q, Mata HP, Vanderah T, Porreca F, Makriyannis A, 2001. CB2 cannabinoid receptor-mediated peripheral antinociception. Pain 93, 239-245.

Maresz K, Carrier EJ, Ponomarev ED, Hillard CJ, Dittel BN, 2005. Modulation of the cannabinoid $\mathrm{CB} 2$ receptor in microglial cells in response to inflammatory stimuli. J. Neurochem. 95, 437-445.

Mechoulam R, Hanus L, 2000. A historical overview of chemical research on cannabinoids. Chem. Phys. Lipids 108, 1-13. 
Molina-Holgado E, Vela JM, Arevalo-Martin A, Almazan G, Molina-Holgado F, Borrell J, Guaza C, 2002. Cannabinoids promote oligodendrocyte progenitor survival: involvement of cannabinoid receptors and phosphatidylinositol-3 kinase/Akt signaling. J. Neurosci. 22, $9742-$ 9753.

Molina-Holgado F, Pinteaux E, Moore JD, Molina-Holgado E, Guaza C, Gibson RM, Rothwell NJ, 2003. Endogenous interleukin-1 receptor antagonist mediates anti-inflammatory and neuroprotective actions of cannabinoids in neurons and glia. J. Neurosci. 23, 6470-6474.

Munro S, Thomas KL, Abu-Shaar M, 1993. Molecular characterization of a peripheral receptor for cannabinoids. Nature 365, 61-65.

Núñez E, Benito C, Pazos MR, Barbachano A, Fajardo O, González S, Tolón R, Romero J, 2004. Cannabinoid CB2 receptors are expressed by perivascular microglial cells in the human brain: an immunohistochemical study. Synapse 53, 208-213.

Núñez E, Benito C, Tolón RM, Hillard CJ, Griffin WS, Romero J, 2007. Glial expression of cannabinoid $\mathrm{CB}(2)$ receptors and fatty acid amide hydrolase are beta amyloid-linked events in Down's syndrome. Neuroscience (in press).

Onaivi ES, Ishiguro H, Gong JP, Patel S, Perchuk A, Meozzi PA, Myers L, Mora Z, Tagliaferro P, Gardner E, Brusco A, Akinshola BE, Liu QR, Hope B, Iwasaki S, Arinami T, Teasenfitz L, Uhl GR, 2006. Discovery of the presence and functional expression of cannabinoid CB2 receptors in brain. Ann. NY Acad. Sci. 1074, 514-536.

Palazuelos J, Aguado T, Egia A, Mechoulam R, Guzmán M, Galve-Roperh I, 2006. Nonpsychoactive CB2 cannabinoid agonists stimulate neural progenitor proliferation. FASEB J. $20,2405-2407$.

Pertwee RG, 2005. Pharmacological actions of cannabinoids. Handb. Exp. Pharmacol. 168, 151. 
Puffenbarger RA, Boothe AC, Cabral GA, 2000. Cannabinoids inhibit LPS-inducible cytokine mRNA expression in rat microglial cells. Glia 29, 58-69.

Raitio KH, Salo OM, Nevalainen T, Poso A, Järvinen T, 2005. Targeting the cannabinoid CB2 receptor: mutations, modeling and development of CB2 selective ligands. Curr. Med. Chem. 12, 1217-1237.

Ramirez BG, Blazquez C, Gomez del Pulgar T, Guzman M, de Ceballos ML, 2005. Prevention of Alzheimer's disease pathology by cannabinoids: neuroprotection mediated by blockade of microglial activation. J. Neurosci. 25, 1904-1913.

Ross RA, Coutts AA, McFarlane SM, Anavi-Goffer S, Irving AJ, Pertwee RG, MacEwan DJ, Scott RH, 2001. Actions of cannabinoid receptor ligands on rat cultured sensory neurones: implications for antinociception. Neuropharmacology 40, 221-232.

Samson MT, Small-Howard A, Shimoda LM, Koblan-Huberson M, Stokes AJ, Turner H, 2003. Differential roles of CB1 and CB2 cannabinoid receptors in mast cells. J. Immunol. $170,4953-4962$.

Sánchez C, de Ceballos ML, del Pulgar TG, Rueda D, Corbacho C, Velasco G, Galve-Roperh I, Huffman JW, Ramón y Cajal S, Guzmán M, 2001. Inhibition of glioma growth in vivo by selective activation of the CB2 cannabinoid receptor. Cancer Res. 61, 5784-5789.

Skaper SD, Buriani A, Dal Toso R, Petrelli L, Romanello S, Facci L, Leon A, 1996. The ALIAmide palmitoylethanolamide and cannabinoids, but not anandamide, are protective in a delayed postglutamate paradigm of excitotoxic death in cerebellar granule neurons. Proc. Natl. Acad. Sci. USA 93, 3984-3989.

Ständer S, Schmelz M, Metze D, Luger T, Rukwied R, 2005. Distribution of cannabinoid receptor 1 (CB1) and 2 (CB2) on sensory nerve fibers and adnexal structures in human skin. J. Dermatol. Sci. 38, 177-188.

Stella N, 2004. Cannabinoid signaling in glial cells. Glia 48, 267-77. 
Sugiura T, Kishimoto S, Oka S, Gokoh M, 2006. Biochemistry, pharmacology and physiology of 2-arachidonoylglycerol, an endogenous cannabinoid receptor ligand. Prog. Lipid Res. 45, 405-446.

van der Stelt M, Di Marzo V, 2005. Cannabinoid receptors and their role in neuroprotection. Neuromolecular Med. 7, 37-50.

Van Sickle MD, Duncan M, Kingsley PJ, Mouihate A, Urbani P, Mackie K, Stella N, Makriyannis A, Piomelli D, Davison JS, Marnett LJ, Di Marzo V, Pittman QJ, Patel KD, Sharkey KA, 2005. Identification and functional characterization of brainstem cannabinoid CB2 receptors. Science 310, 329-332.

Walter L, Franklin A, Witting A, Wade C, Xie Y, Kunos G, Mackie K, Stella N, 2003. Nonpsychotropic cannabinoid receptors regulate microglial cell migration. J. Neurosci. 23, 1398-1405.

Wotherspoon G, Fox A, McIntyre P, Colley S, Bevan S, Winter J, 2005. Peripheral nerve injury induces cannabinoid receptor 2 protein expression in rat sensory neurons. Neuroscience $135,235-245$.

Yiangou Y, Facer P, Durrenberger P, Chessell IP, Naylor A, Bountra C, Banati RR, Anand P, 2006. COX-2, CB2 and P2X7-immunoreactivities are increased in activated microglial cells/macrophages of multiple sclerosis and amyotrophic lateral sclerosis spinal cord. BMC Neurol. 6, 12.

Zhang J, Hoffert C, Vu HK, Groblewski T, Ahmad S, O'Donnell D, 2003. Induction of CB2 receptor expression in the rat spinal cord of neuropathic but not inflammatory chronic pain models. Eur. J. Neurosci. 17, 2750-2754.

Zhang M, Martin BR, Adler MW, Razdan RK, Jallo JI, Tuma RF, 2007. Cannabinoid CB2 receptor activation decreases cerebral infarction in a mouse focal ischemia/reperfusion model.. J. Cereb. Blood Flow. Metab. 27, 1387-1396. 
Figure 1. Role of glial cells in $\mathbf{C B}_{2}$ receptor-mediated neuroprotection. $\mathrm{CB}_{2}$ receptors are located in reactive microglia and astrocytes and they play a role in the endogenous response against neurodegenerative/neuroinflammatory stimuli.
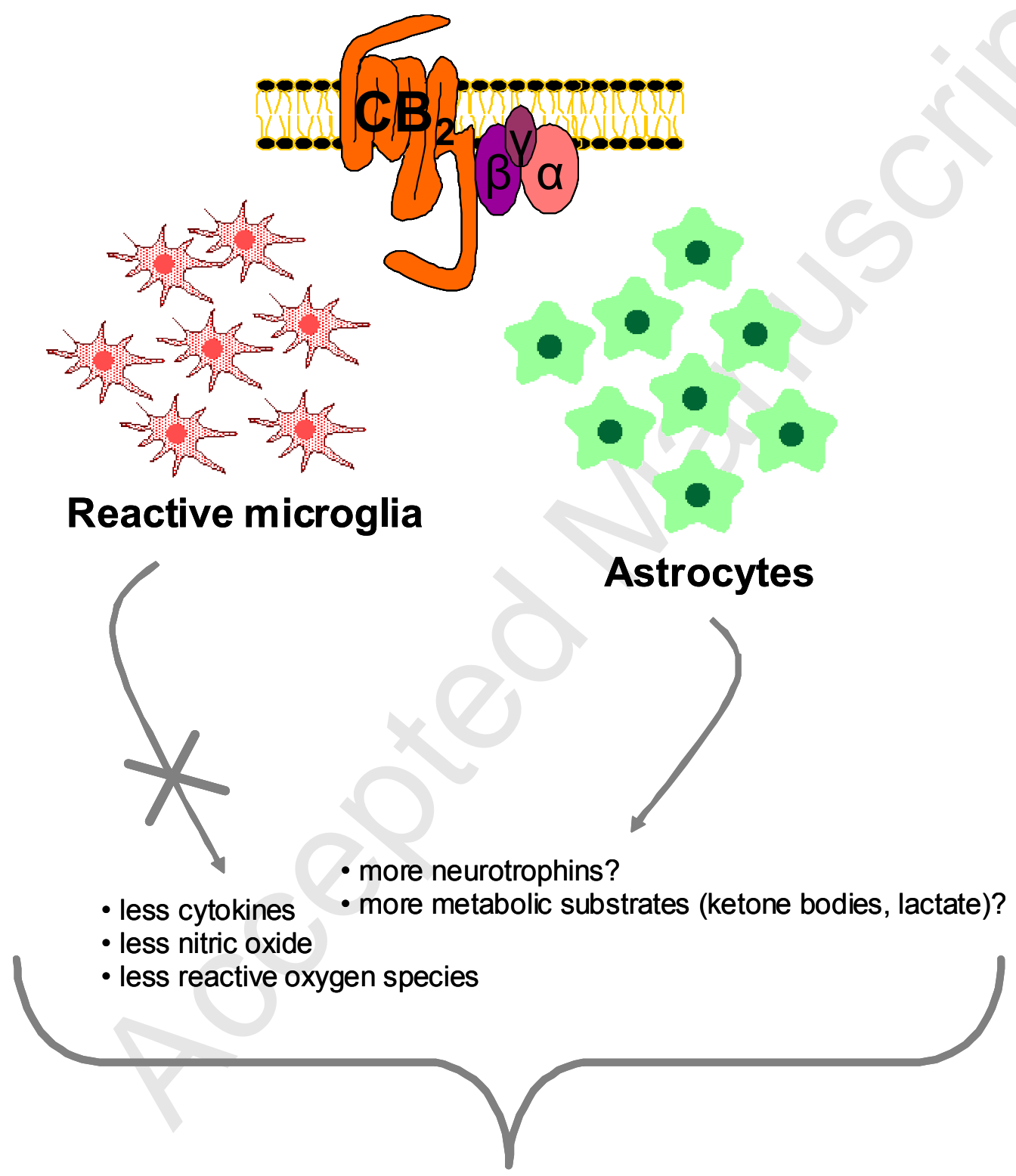

NEUROPROTECTION 